\title{
The Role of TROP2 in BCC and Cutaneous SCC: A Clinical and Immunohistochemical Study
}

\author{
Azza Gaber Antar Farag (1) \\ Hala Said El-Rebey ${ }^{2}$ \\ Mohamed Abd \\ El-Moneim Shoeib' \\ Shimaa Mohammed Ahmed \\ El-Fiky $^{3}$ \\ Mustafa Elsayed Elshaib (D) ${ }^{4}$ \\ Amal Farid Mostafa ${ }^{2}$ \\ 'Dermatology, Andrology and STDs \\ Department, Faculty of Medicine, \\ Menoufia University, Shebin ElKom, \\ Egypt; ${ }^{2}$ Pathology Department, Faculty of \\ Medicine, Menoufia University, Shebin \\ EIKom, Egypt; ${ }^{3}$ Department of \\ Dermatology, Ministry of Health, \\ AIMahala General Hospital, Shebin \\ ElKom, Egypt; ${ }^{4}$ Faculty of Medicine, \\ Menoufia University, Shebin ElKom, Egypt
}

Correspondence: Azza Gaber Antar Farag

Dermatology, Andrology and STDs

Department, Faculty of Medicine,

Menoufia University, Al-Menoufia, Gamal

AbdElnasser Street, 325I, Shebin EIKom,

325II, Egypt

Tel +20 1097787204

Fax +20 482226454

Email azzagaber92@yahoo.com
Background: Nonmelanoma skin cancer (NMSC) mainly includes basal (BCC) and squamous (SCC) cell carcinoma. Trophoblast cell-surface antigen2 (TROP2), a cell-signal transduction, is one of the tumor-related calcium signal transducer gene family. TROP2 was highly expressed in many cancers, however, its role in BCC and SCC has not yet been studied.

Objective: To investigate TROP2 immunohistochemical expression in BCC and SCC (lesional and peri-lesional) skin compared to controls and correlates its expression with the clinicopathologic parameters of the studied cases.

Methods: This case-control study included 17 BCC and 15 SCC patients as well as 12 age and sex matched controls. History and clinical examination were completed. Histological examination of skin biopsies was done together with TROP2 immune-staining.

Results: In the studied BCC and SCC cases, there was a significant stepwise up-regulation of TROP2 $\mathrm{H}$ score from control to peri-lesional, ended by lesional epidermis in one hand $(p=0.003$ for $\mathrm{BCC}$ and $\mathrm{p}<0.001$ for SCC) and tumor island in another hand $(\mathrm{p}=0.001$ for BCC and $\mathrm{p}=0.003$ for SCC). TROP2 expression in both BCC and SCC tumor tissues was not affected by any of the studied clinicopathological parameters of the investigated cases.

Conclusion: TROP2 could have an important role in BCC and SCC pathogenesis. TROP2 targeting may have appraising effect in clinical application in BCC and SCC management. Keywords: BCC, SCC, TROP2, clinical, immunohistochemical

\section{Introduction}

Nonmelanoma skin cancer (NMSC) refers to all the types of cancer that occur in the skin other than melanoma. It represents a wide disease spectrum ranging from lowrisk to high-risk skin tumors. Numerous types of skin tumors are found within the category of NMSC, with the most common varieties being SCC and BCC. ${ }^{1}$ Incidence of the skin cancers are by far the most common of all types of cancer. Approximately 5.4 million SCC and BCC are diagnosed yearly in the United States and about $80 \%$ of them were BCCs. ${ }^{2}$ In Egypt, NMSC represents around $1.3 \%$ of all cancers, ${ }^{3}$ with BCC being more common than SCC. ${ }^{4}$

$\mathrm{BCC}$, the most common type of NMSC in humans, is characterized by a constantly increasing incidence with significant complications. ${ }^{5}$ It arises from the basal layer of the epidermis or appendages ${ }^{6}$ mostly on sun-exposed areas, especially head and neck, ${ }^{7}$ where most of lesions are of nodular morphology. ${ }^{8}$

SCC, the second recorded common NMSC, is of keratinocyte origin. ${ }^{9}$ It involves the trunk and other body parts $^{10}$ and is mainly categorized histologically as well, moderately or poorly differentiated. ${ }^{11}$ 
The human TROP2 is a cell-surface glycoprotein that was described for the first time as a protein highly expressed on cell surface of trophoblasts. ${ }^{12}$ It consists of 323 amino acids $^{13}$ and has extracellular domain, short transmembrane domain and a cytoplasmic tail. ${ }^{14}$

TROP2 message is detected in many normal human tissues, including skin, suggesting its important function in ordinary situations. ${ }^{15,16}$ It has been implicated in numerous intracellular signaling pathways as transducing calcium signals. ${ }^{17}$ It can also activate extracellular signal regulated kinase (ERK) providing essential signals required for cell proliferation, survival and selfrenewal. ${ }^{18}$ Additionally, TROP2 was reported to have stem cell-like abilities regulating cell growth, regeneration, transformation and proliferation. ${ }^{19}$ Furthermore, TROP2 has an ability to function as an adhesion molecule for epithelial cells, as its extracellular domain shares a conserved cysteine-rich region with epithelial-specific cell adhesion molecule. ${ }^{20}$

In tumor cells, TROP2 has dual functions as it can act as tumor suppressor gene or an oncogene. ${ }^{21}$ Although it is down-regulated in cholangiocarcinoma, ${ }^{21}$ TROP2 was highly expressed in various human cancers as lung, ${ }^{22}$ cervix ${ }^{23}$ and oral SCC. ${ }^{24,25}$ Regarding BCC and cutaneous SCC, the role of TROP2 was not yet identified.

In this study, we tried to investigate the role of TROP2 in BCC and cutaneous SCC through evaluation of its immunohistochemical expression in lesional and perilesional skin of patients compared to healthy controls, in addition to, correlating this expression with the available clinicopathologic parameters in those patients.

\section{Patients and Methods}

This case-control prospective study included 44 subjects. They were 12 apparently healthy volunteers (controls group), 17 patients having BCC (45 to 80 years) and 15 cases having SCC (46 to 75 years). BCC and SCC patients were selected from Dermatology Outpatient Clinic, Menoufia University Hospital during the period between March 2018 and April 2019. The study protocol was approved by the Ethical Committee of Human Right of Research at Menoufia University (IRB approval number; 1001/7/4/2019DERM), that was in accordance with the Declaration of Helsinki. An informed written consent was signed by every participant before the study initiation.

We included newly diagnosed cases of BCC and SCC from both sexes. We excluded those who received any treatment for SCC or BCC in the past 6 months. Also, patients having any other skin diseases were excluded. The investigated controls were selected from those attending Plastic Surgery Clinic having no relevant skin diseases, and were age (44-70 years) and sex ( 9 males and 3 females) matched with the studied patients.

For the all cases, complete history taking and general examination were performed. Dermatological examination was done for the presenting lesion to asses its site, size and shape (mass or ulcer). In case of ulcers, we also examined the base, floor and edges of each one.

Skin biopsies, either incisional or excisional, were taken from lesional tissues of BCC and SCC patients and their peri-lesional tissues $(0.5 \mathrm{~cm}$ away from the affected skin), ${ }^{26}$ and from matched sites of controls. The biopsies were sent to Pathology Department, faculty of Medicine, Menoufia University for routine tissue processing with paraffin-embedded blocks formation. From each block $4 \mu \mathrm{m}$ thick sections were cut; one to be stained by haematoxylin and eosin (H\&E) for diagnosis either BCC or SCC and evaluation of the tumor margins together with grade in SCC. Other sections were mounted on positive charged slides for immunohistochemical staining (one test slide and one negative control slide). The method used for immunostaining was streptavidin-biotin amplified system. The primary antibody was rabbit polyclonal antibody raised against TROP2. It was received as $0.1 \mathrm{~mL}$ concentrated with a dilution of 1:200 (Biorbyt Ltd, Cambridge, United Kingdom Cat. orb11521). The detection Kit was the ultravision detection system anti-polyvalent horse radish peroxidase/diaminobenzidine (HRP/DAB) (Ready to use; Dako, Ref K8000, Glostrup, Denmark). A positive reaction was detected using $\mathrm{DAB}$ as a substratechromogen solution. Slides of normal prostate were used as a positive control for each run. Negative control slides were used for each run by omitting the primary antibody.

TROP2 was evaluated in epidermis and tumor islands of BCC and SCC cases and epidermis of peri-lesional and control tissues as follows: 1) Either positive or negative where positivity was considered by membranocytoplasmic or cytoplasmic staining in any percentage of cells. 2) The intensity was graded subjectively and blindly by two pathologists independently, as mild, moderate and strong. 3) Histo-score (H score): was evaluated for studied cases as follows: $\mathrm{H}$ score $=\%$ of mild stained cells $\mathrm{x} 1+\%$ of moderate stained cells $\times 2+\%$ of strong stained cells $\times 3$. 


\section{Statistical Analysis}

Data were collected, tabulated, and statistically analyzed using a personal computer with the "Statistical Package for the Social Sciences" (SPSS) version 20 program (SPSS Inc., Chicago, IL, US). Chi-square test was used for evaluation of qualitative data while Mann-Whitney, F-test (ANOVA), Kruskal-Wallis and Post Hoc (Dunn's multiple comparisons) tests were used for evaluation of quantitative data. $P<.05$ was considered significant.

\section{Results}

Personal and Clinical Data of the Studied Subjects

The clinic-pathological data of the studied cases and controls are demonstrated in Table 1. BCC patients had age ranged from 45 to 80 years and $58.8 \%$ of them were males in comparison to 46 to 75 years and $80 \%$ males in SCC as well as 44 to 70 years and $75 \%$ males in controls with a non-significant difference between the studied groups regarding age $(p=0.105)$, and $\operatorname{sex}(p=0.415)$.

Table I Personal, Clinical and Pathological Data of the Studied Subjects

\begin{tabular}{|c|c|c|c|c|c|c|c|c|}
\hline & \multicolumn{2}{|c|}{$\begin{array}{l}\text { Control } \\
(\mathrm{N}=12)\end{array}$} & \multicolumn{2}{|c|}{$\begin{array}{c}\text { BCC } \\
(N=\mid 7)\end{array}$} & \multicolumn{2}{|c|}{$\begin{array}{c}\operatorname{sCC} \\
(N=15)\end{array}$} & \multirow[t]{2}{*}{ Test } & \multirow[t]{2}{*}{$\mathbf{p}$} \\
\hline & $\mathbf{N}$ & $\%$ & $\mathbf{N}$ & $\%$ & $\mathbf{N}$ & $\%$ & & \\
\hline \multicolumn{9}{|l|}{ Age (years) } \\
\hline $\begin{array}{l}\text { - Min. - Max. } \\
\text { - Mean } \pm \text { SD. } \\
\text { Median }\end{array}$ & \multicolumn{2}{|c|}{$\begin{array}{c}44.0-70.0 \\
57.67 \pm 7.46 \\
57.50\end{array}$} & \multicolumn{2}{|c|}{$\begin{array}{c}45.0-80.0 \\
65.06 \pm 9.20 \\
65.0\end{array}$} & \multicolumn{2}{|c|}{$\begin{array}{c}46.0-75.0 \\
61.47 \pm 9.88 \\
65.0\end{array}$} & $F=2.38 I$ & 0.105 \\
\hline \multicolumn{9}{|l|}{ Sex } \\
\hline $\begin{array}{l}\text { - Male } \\
\text { - Female }\end{array}$ & $\begin{array}{l}9 \\
3\end{array}$ & $\begin{array}{l}75.0 \\
25.0\end{array}$ & $\begin{array}{l}10 \\
7\end{array}$ & $\begin{array}{l}58.8 \\
41.2\end{array}$ & $\begin{array}{c}12 \\
3\end{array}$ & $\begin{array}{l}80.0 \\
20.0\end{array}$ & $\chi 2=1.788$ & 0.415 \\
\hline \multicolumn{9}{|l|}{ Site } \\
\hline $\begin{array}{l}\text { - Extremities } \\
\text { - Head and neck } \\
\text { - Scalp } \\
\text { - Face }\end{array}$ & $\begin{array}{l}- \\
- \\
-\end{array}$ & $\begin{array}{l}- \\
- \\
-\end{array}$ & $\begin{array}{c}0 \\
17 \\
4 \\
13\end{array}$ & $\begin{array}{l}0.0 \\
100 \\
23.5 \\
76.5\end{array}$ & $\begin{array}{l}8 \\
7 \\
7 \\
0\end{array}$ & $\begin{array}{c}53.3 \\
46.7 \\
46.7 \\
0.0\end{array}$ & & \\
\hline \multicolumn{9}{|l|}{ Type of biopsy } \\
\hline $\begin{array}{l}\text { - Excisional } \\
\text { - Incisional }\end{array}$ & - & - & $\begin{array}{c}13 \\
4\end{array}$ & $\begin{array}{l}76.5 \\
23.5\end{array}$ & $\begin{array}{c}15 \\
0\end{array}$ & $\begin{array}{c}100.0 \\
0.0\end{array}$ & & \\
\hline \multicolumn{9}{|l|}{ Type of the lesion } \\
\hline $\begin{array}{l}\text { - Mass (Nodular) } \\
\text { - Ulcer }\end{array}$ & - & - & $\begin{array}{c}6 \\
11\end{array}$ & $\begin{array}{l}35.3 \\
64.7\end{array}$ & $\begin{array}{c}5 \\
10\end{array}$ & $\begin{array}{l}33.3 \\
66.7\end{array}$ & & \\
\hline \multicolumn{9}{|l|}{ Margin } \\
\hline $\begin{array}{l}\text { - Free } \\
\text { - Involved } \\
\text { - Cannot be assessed }\end{array}$ & $\begin{array}{l}- \\
- \\
-\end{array}$ & $\begin{array}{l}- \\
- \\
-\end{array}$ & $\begin{array}{c}12 \\
4 \\
1\end{array}$ & $\begin{array}{c}70.6 \\
23.5 \\
5.9\end{array}$ & $\begin{array}{l}7 \\
7 \\
1\end{array}$ & $\begin{array}{c}46.7 \\
46.7 \\
6.7\end{array}$ & & \\
\hline \multicolumn{9}{|l|}{ Grade } \\
\hline $\begin{array}{l}\bullet \text { I } \\
\bullet \text { II } \\
\bullet \text { III }\end{array}$ & $\begin{array}{l}- \\
- \\
-\end{array}$ & $\begin{array}{l}- \\
- \\
-\end{array}$ & $\begin{array}{l}- \\
- \\
-\end{array}$ & $\begin{array}{l}- \\
- \\
-\end{array}$ & $\begin{array}{c}10 \\
3 \\
2\end{array}$ & $\begin{array}{l}66.7 \\
20.0 \\
13.3\end{array}$ & & \\
\hline
\end{tabular}

Notes: F: ANOVA test; $\chi 2$ : Chi-square test.

Abbreviations: BCC, basal cell carcinoma; SCC, squamous cell carcinoma; SD, standard deviation; N, number. 


\section{TROP2 Immostainning of the Studied \\ Groups}

In control group (Figure 1), TROP2 immunoreactivity was observed in epidermal keratinocytes of 9 cases $(75 \%)$ having $\mathrm{H}$ score ranged from 20 to 80 with a mean $\pm \mathrm{SD}$ of $38.89 \pm 20.28$.

In BCC cases (Figures 1 and 2), TROP2 was expressed in the lesional skin; overlying epidermis (13 cases, $76.5 \%$ ) having $\mathrm{H}$ score ranged from 30 to 160 with a mean \pm SD of $93.85 \pm 43.50$, and tumor islands (15 cases, $88.2 \%$ ) where $\mathrm{H}$ score ranged from 30 to 210 and its mean $\pm \mathrm{SD}$ was $109.33 \pm 50.49$. Peri-lesional tissues were available for 14 cases, TROP2 was expressed in overlying epidermis of $6 / 114$ cases $(42.9 \%)$ where $\mathrm{H}$ score ranged from 50 to 100 with $76.67 \pm 19.66$ as mean \pm SD.

Regarding SCC cases (Figures 1 and 3), TROP2 was expressed in the lesional skin; overlying epidermis (11 cases, $73.3 \%$ ) where $\mathrm{H}$ score mean $\pm \mathrm{SD}$ was140.91 \pm 62.36 and tumor islands (14 cases, 93.3\%) where H score mean \pm SD was $94.29 \pm 39.75$. Peri-lesional tissues were available for 12 cases, TROP2 was expressed in overlying epidermis of $6 / 12$ cases $(50 \%)$ where $\mathrm{H}$ score range was 40 to 70 and the mean \pm SD was $60.0 \pm 15.49$.

A significant difference was reported between the three studied groups (control, BCC and SCC) regarding TROP2 $\mathrm{H}$ scores in peri-lesional epidermis $(0.012)$, lesional epidermis $(<0.001)$ as well as tumor islands $(0.002)$. However, comparing TROP2 expression and $\mathrm{H}$ scores in both BCC and SCC cases did not reveal any significant difference (Table 2).

Comparison between controls and $\mathrm{BCC}$ cases revealed a significant stepladder increase of TROP2 $\mathrm{H}$ score from control (38.89 \pm 20.28$)$ to BCC peri-lesional epidermis $(76.67 \pm 19.66)(\mathrm{p}=0.018)$, ended by its highest values in

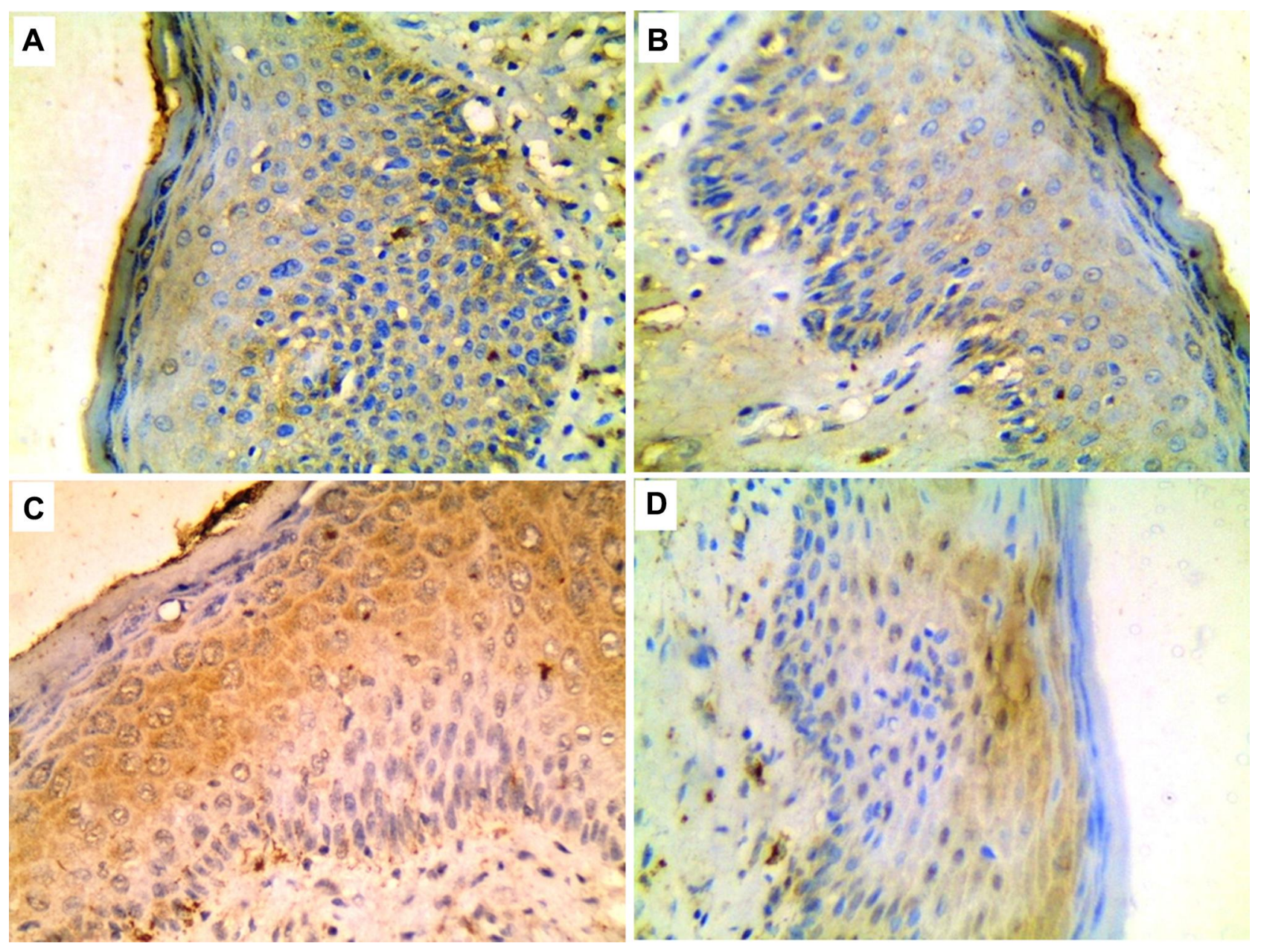

Figure I Mild positive membrano-cytoplasmic expression of TROP2 in epidermis of; (A) normal control and (B) BCC peri-lesional tissue. Moderate positive cytoplasmic expression of TROP2 in epidermis of; (C) BCC and (D) SCC (Immunoperoxidase $\times 400$ for all). 

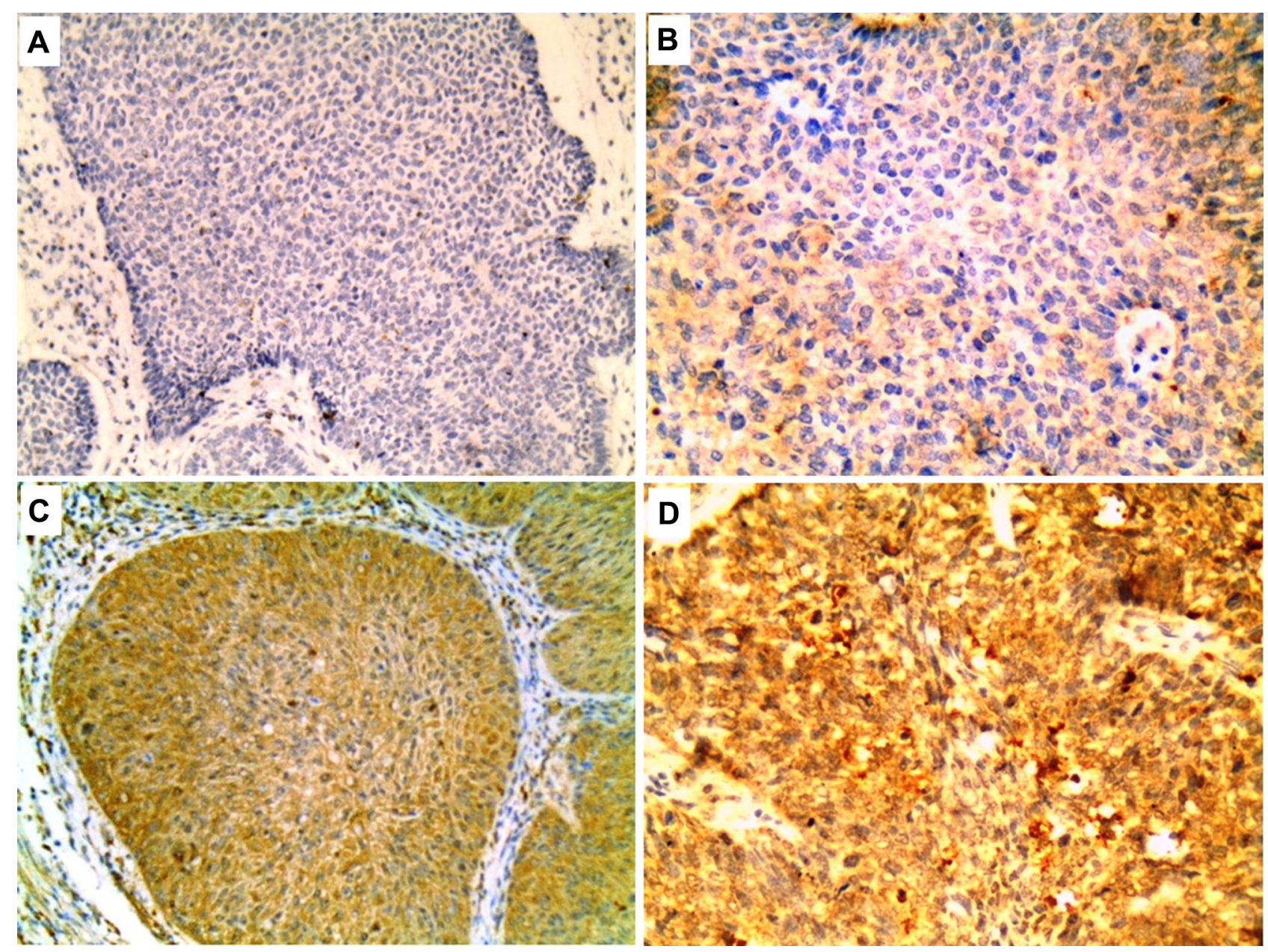

Figure 2 Tumor islands of BCC showing; (A) negative, (B) mild positive, (C) moderate positive and (D) strong positive TROP2 expression (Immunoperoxidase x200 for A and $C ; \times 400$ for $B$ and $D$ ).

BCC skin lesional epidermis $(93.85 \pm 43.50)(\mathrm{p}=0.003)$ when the three groups are compared. A similar relationship were obtained on comparing tumor islands TROP2 H Score $(109.33 \pm 50.49)$ with that of control and perilesional ones $(p=0.001)$. Furthermore, both lesional epidermis and tumor islands showed a significantly higher $\mathrm{H}$ scores of TROP2 when each of them was compared to normal controls $(\mathrm{p}<0.001$ and $\mathrm{p}=0.001$, respectively) with a non-significant difference between both of them $(\mathrm{p}=0.141)$ (Table 3).

Similarly, the comparison between controls and SCC cases revealed a significant stepwise increase of TROP2 $\mathrm{H}$ score from control $(38.89 \pm 20.28)$ to SCC peri-lesional epidermis $(60.0 \pm 15.49)$ ended by SCC skin lesional epidermis $(140.91 \pm 62.36)(\mathrm{p}<0.001)$ when the three groups are compared. A similar relationship were obtained on comparing tumor islands TROP2 H Score $(94.29 \pm 39.75)$ with that of control and peri-lesional ones $(\mathrm{p}=0.003)$. Additionally, both lesional epidermis and tumor islands showed a significantly higher $\mathrm{H}$ scores of TROP2 when each of them was compared to normal controls $(\mathrm{p}<0.001$ and $\mathrm{p}=0.001$, respectively) with a non-significant difference between both of them $(\mathrm{p}=0.109)$ (Table 4$)$.

\section{Relationships Between TROP2 H Scores of Tumor Islands and Clinicopathological Parameters of BCC and SCC Patients}

TROP2 expression in both BCC and SCC tumor islands was not affected by any of the studied clinicopathological parameters of the investigated cases (data not shown).

\section{Discussion}

Although rarely fatal, BCC can be extremely destructive causing local tissue disfigurement particularly if treatment is 


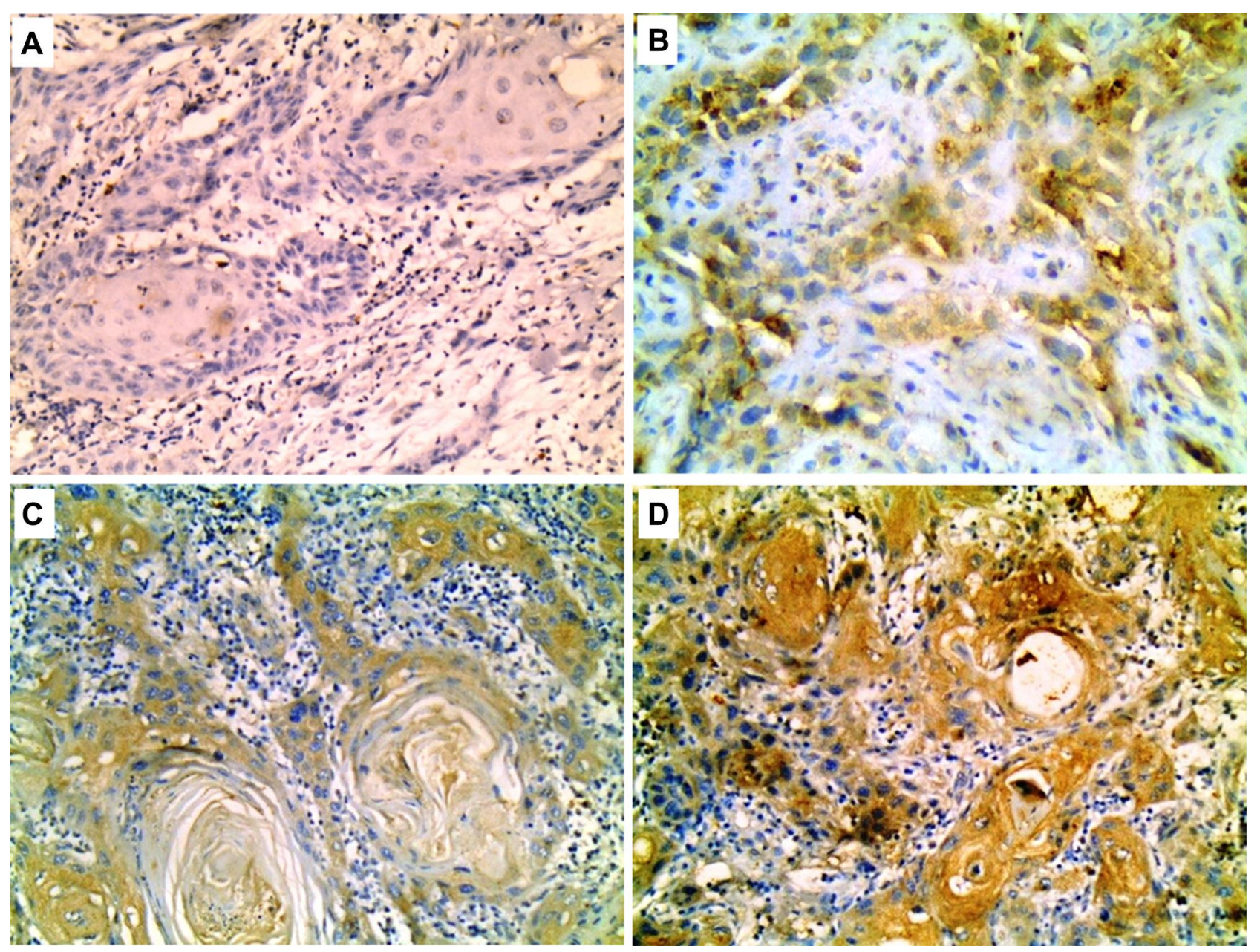

Figure 3 Tumor islands of SCC showing; (A) negative TROP2 expression in poorly differentiated case, (B) mild, (C) moderate and (D) strong TROP2 positivity in well differentiated cases (Immunoperoxidase $\times 200$ for A, C and D; x400 for B).

delayed or inadequate. ${ }^{27}$ Regarding SCC, the majority of head and neck cases require complicated surgery which can cause deformities ${ }^{28}$ with $10-18 \%$ local recurrence. ${ }^{29}$ Consequently, it is authoritative to determine biologic elements associated with $\mathrm{BCC}$ as well as SCC that may help in treatment.

TROP2, the know member of the tumor-related calcium transducer gene family, ${ }^{16}$ could be targeted to reduce its expression and, accordingly, to inhibit the tumor progression and decline its size. One human clinical trial, using IMMU-132 (the antibody conjugate), was under way for Phase I and II treatments of epithelial cancer cells expressing TROP $2 .{ }^{30}$

Herein, we tried to investigate, for the first time, if TROP2 has any association with BCC and/or SCC, through evaluation of its immunohistochemical expression in BCC and SCC patients compared to healthy controls.

The current work revealed a significant up-regulation of TROP2 $\mathrm{H}$ score in peri-lesional epidermis, lesional epidermis as well as tumor islands of BCC and SCC when compared to normal controls with a non-significant difference between both BCC and SCC groups. Furthermore, in each tumor, there was a significant stepladder increase of TROP2 $\mathrm{H}$ score from control to perilesional epidermis, ended by skin lesional epidermis on one hand and with tumor islands on the other hand indicating an important function of TROP2 in both tumors' development. Therefore, we proposed that, TROP2 might have a dynamic role in the pathogenesis of both $\mathrm{BCC}$ and SCC and subsequently, TROP2 targeting may have appraising effect in clinical application in BCC and SCC managing program.

Likewise, Stepan et $\mathrm{al}^{31}$ reported that TROP2 was expressed in various types of adenocarcinomas. As well, TROP2 overexpression was demonstrated in many human cancer cell types ${ }^{30}$ including SCC of the oral cavity. ${ }^{24,32,33}$ Additionally, Nakashima et $\mathrm{al}^{34}$ recognized serum anti- 
Table 2 Comparison Between the Studied Groups (Control, BCC and SCC) Regarding TROP2 Expression and H Score

\begin{tabular}{|c|c|c|c|c|c|c|c|c|c|}
\hline \multirow[t]{2}{*}{ TROP2 } & \multicolumn{2}{|c|}{ Control Epidermis } & \multicolumn{2}{|c|}{ BCC } & \multicolumn{2}{|c|}{ SCC } & \multirow[t]{2}{*}{ Test } & \multirow[t]{2}{*}{$\mathbf{p}$} & \multirow[t]{2}{*}{ Post Hoc Test } \\
\hline & $\mathbf{N}$ & $\%$ & $\mathbf{N}$ & $\%$ & $\mathbf{N}$ & $\%$ & & & \\
\hline Peri-lesion epidermis & \multicolumn{2}{|c|}{$(N=12)$} & \multicolumn{2}{|c|}{$(N=14)$} & \multicolumn{2}{|c|}{$(N=12)$} & \multirow[t]{3}{*}{$\chi^{2}=2.897$} & \multirow[t]{3}{*}{0.235} & \multirow[t]{3}{*}{$P_{1}=0.716$} \\
\hline Negative & 3 & 25.0 & 8 & 57.1 & 6 & 50.0 & & & \\
\hline Positive & 9 & 75.0 & 6 & 42.9 & 6 & 50.0 & & & \\
\hline \multicolumn{7}{|l|}{ H score } & \multirow[t]{4}{*}{$\mathrm{H}=8.846^{*}$} & \multirow[t]{4}{*}{$0.012 *$} & \multirow[t]{4}{*}{$P_{1}=0.288$} \\
\hline Min. - Max. & \multirow{3}{*}{\multicolumn{2}{|c|}{$\begin{array}{c}20.0-80.0 \\
38.89 \pm 20.28 \\
40.0\end{array}$}} & \multirow{3}{*}{\multicolumn{2}{|c|}{$\begin{array}{c}50.0-100.0 \\
76.67 \pm 19.66 \\
80.0\end{array}$}} & \multirow{3}{*}{\multicolumn{2}{|c|}{$\begin{array}{c}40.0-70.0 \\
60.0 \pm 15.49 \\
70.0\end{array}$}} & & & \\
\hline Mean \pm SD. & & & & & & & & & \\
\hline Median & & & & & & & & & \\
\hline Lesion epidermis & \multicolumn{2}{|c|}{$(N=12)$} & \multicolumn{2}{|c|}{$(N=\mid 7)$} & \multicolumn{2}{|c|}{$(N=\mid 5)$} & \multirow[t]{3}{*}{$\chi^{2}=0.176$} & \multirow[t]{3}{*}{1.000} & \multirow[t]{3}{*}{$P_{1}=1.000$} \\
\hline Negative & 3 & 25.0 & 4 & 23.5 & 4 & 26.7 & & & \\
\hline Positive & 9 & 75.0 & 13 & 76.5 & 11 & 73.3 & & & \\
\hline \multicolumn{7}{|l|}{ H score } & \multirow[t]{4}{*}{$\mathrm{H}=16.129 *$} & \multirow[t]{4}{*}{$<0.00 I^{*}$} & \multirow[t]{4}{*}{$P_{1}=0.153$} \\
\hline Min. - Max & \multirow{3}{*}{\multicolumn{2}{|c|}{$\begin{array}{c}20.0-80.0 \\
38.89 \pm 20.28 \\
40.0\end{array}$}} & \multirow{3}{*}{\multicolumn{2}{|c|}{$\begin{array}{c}30.0-160.0 \\
93.85 \pm 43.50 \\
90.0\end{array}$}} & & 30.0 & & & \\
\hline Mean \pm SD. & & & & & 140 & 62.36 & & & \\
\hline Median & & & & & & & & & \\
\hline Tumor islands & & & & 17) & & 15) & $\chi^{2}=|.87|$ & 0.471 & $P_{1}=1.000$ \\
\hline Negative & 3 & 25.0 & 2 & 11.8 & I & 6.7 & & & \\
\hline Positive & 9 & 75.0 & 15 & 88.2 & 14 & 93.3 & & & \\
\hline H score & & & & & & & $\mathrm{H}=\left.12.62\right|^{*}$ & $0.002^{*}$ & $P_{1}=0.725$ \\
\hline Min. - Max. & & & & 10.0 & & 60.0 & & & \\
\hline Mean \pm SD. & & .28 & 109 & 50.49 & & 39.75 & & & \\
\hline Median & & & & & & & & & \\
\hline
\end{tabular}

Notes: $\chi^{2}$ : Chi-square test. $\mathrm{H}: \mathrm{H}$ for Kruskal-Wallis test, Pairwise comparison between BCC and SCC was done using Post Hoc Test (Dunn's for multiple comparisons test). $\mathrm{p}$ : $\mathrm{p}$ value for comparing between the studied groups. $\mathrm{PI}$ : $\mathrm{p}$ value for comparing between $\mathrm{BCC}$ and $\mathrm{SCC}$. *Statistically significant at $\mathrm{p} \leq 0.05$.

Abbreviation: N, number.

Table 3 Relationship Between Controls, BCC Peri-Lesions and Lesions (Epidermis and Tumor Islands) Regarding TROP2 H Score

\begin{tabular}{|c|c|c|c|c|c|c|}
\hline \multirow{2}{*}{$\begin{array}{l}\text { TROP2 } \\
\text { H Score }\end{array}$} & \multirow{2}{*}{$\begin{array}{c}\text { Control } \\
\text { Epidermis } \\
(\mathrm{N}=12)\end{array}$} & \multicolumn{2}{|c|}{ BCC } & \multirow[t]{2}{*}{$\mathbf{H}$} & \multirow[t]{2}{*}{$\mathbf{p}$} & \multirow{2}{*}{$\begin{array}{c}\text { Post Hoc } \\
\text { Test }\end{array}$} \\
\hline & & $\begin{array}{l}\text { Peri-Lesion Epidermis } \\
\qquad(\mathrm{N}=14)\end{array}$ & $\begin{array}{l}\text { Lesion Epidermis } \\
\qquad(\mathrm{N}=\mid 7)\end{array}$ & & & \\
\hline Min. - Max. & $20.0-80.0$ & $50.0-100.0$ & $30.0-160.0$ & II.797 & $0.003 *$ & $\mathrm{P}_{1}=0.018 *$ \\
\hline Mean \pm SD. & $38.89 \pm 20.28$ & $76.67 \pm 19.66$ & $93.85 \pm 43.50$ & & & $\mathrm{P}_{2}=0.00 \mathrm{I} *$ \\
\hline \multirow[t]{2}{*}{ Median } & 40.0 & 80.0 & 90.0 & & & $P_{3}=0.682$ \\
\hline & $\begin{array}{l}\text { Epidermis } \\
\qquad(\mathrm{N}=12)\end{array}$ & $\begin{array}{l}\text { Peri-Lesion Epidermis } \\
\qquad(\mathrm{N}=14)\end{array}$ & Tumor Islands $(\mathrm{N}=\mid 7)$ & & & \\
\hline Min. - Max. & $20.0-80.0$ & $50.0-100.0$ & $30.0-210.0$ & $13.980 *$ & $0.001 *$ & $P_{1}=0.075$ \\
\hline Mean \pm SD & $38.89 \pm 20.28$ & $76.67 \pm 19.66$ & $109.33 \pm 50.49$ & & & $\mathrm{P}_{2}<0.001 *$ \\
\hline \multirow[t]{2}{*}{ Median } & 40.0 & 80.0 & 110.0 & & & $P_{3}=0.186$ \\
\hline & & & & & & $\mathrm{P}_{4}=0.14 \mathrm{I}$ \\
\hline
\end{tabular}

Notes: H: Kruskal-Wallis test, Pairwise comparison between each 2 groups was done using Post Hoc Test (Dunn's for multiple comparisons test). p: $\mathrm{p}$ value for comparing between the studied groups. $\mathrm{p}_{1}: \mathrm{p}$ value for comparing between control and peri-lesion BCC. $\mathrm{p}_{2}: \mathrm{p}$ value for comparing between control and lesion $\mathrm{BCC}$. $\mathrm{P}_{3}: \mathrm{p}$ value for comparing between peri-lesion $B C C$ and lesion $B C C$. $\mathrm{p}_{4}$ : $\mathrm{p}$ value for comparing between lesion epidermis $\mathrm{BCC}$ and tumor islands $\mathrm{BCC}$. *Statistically significant at $\mathrm{p} \leq 0.05$. Abbreviations: $\mathrm{N}$, number; $\mathrm{SD}$, standard deviation. 
Table 4 Relationship Between Controls, SCC Peri-Lesions and Lesions (Epidermis and Tumor Islands) Regarding TROP2 H Score

\begin{tabular}{|c|c|c|c|c|c|c|}
\hline \multirow{2}{*}{$\begin{array}{l}\text { TROP2 } \\
\text { H Score }\end{array}$} & \multirow{2}{*}{$\begin{array}{l}\text { Control } \\
\text { Epidermis } \\
(\mathrm{N}=12)\end{array}$} & \multicolumn{2}{|c|}{ SCC } & \multirow[t]{2}{*}{$\mathbf{H}$} & \multirow[t]{2}{*}{$\mathbf{p}$} & \multirow{2}{*}{$\begin{array}{c}\text { Post Hoc } \\
\text { Test }\end{array}$} \\
\hline & & $\begin{array}{l}\text { Peri-Lesion Epidermis } \\
\qquad(\mathrm{N}=\mid 2)\end{array}$ & $\begin{array}{l}\text { Lesion Epidermis } \\
\qquad(\mathrm{N}=15)\end{array}$ & & & \\
\hline $\begin{array}{l}\text { Min. - Max. } \\
\text { Mean } \pm \text { SD. } \\
\text { Median }\end{array}$ & $\begin{array}{c}20.0-80.0 \\
38.89 \pm 20.28 \\
40.0\end{array}$ & $\begin{array}{c}40.0-70.0 \\
60.0 \pm 15.49 \\
70.0\end{array}$ & $\begin{array}{c}60.0-230.0 \\
|40.9| \pm 62.36 \\
150.0\end{array}$ & 15.698* & $<0.00 I^{*}$ & $\begin{array}{l}\mathrm{P}_{1}=0.177 \\
\mathrm{P}_{2}<0.00 I^{*} \\
\mathrm{P}_{3}=0.038^{*}\end{array}$ \\
\hline & $\begin{array}{l}\text { Epidermis } \\
(\mathrm{N}=12)\end{array}$ & $\begin{array}{l}\text { Peri-Lesion Epidermis } \\
\qquad(\mathrm{N}=12)\end{array}$ & $\begin{array}{l}\text { Tumor Islands } \\
\qquad(\mathrm{N}=15)\end{array}$ & & & \\
\hline $\begin{array}{l}\text { Min. - Max. } \\
\text { Mean } \pm \text { SD. } \\
\text { Median }\end{array}$ & $\begin{array}{c}20.0-80.0 \\
38.89 \pm 20.28 \\
40.0\end{array}$ & $\begin{array}{c}40.0-70.0 \\
60.0 \pm 15.49 \\
70.0\end{array}$ & $\begin{array}{c}30.0-160.0 \\
94.29 \pm 39.75 \\
105.0\end{array}$ & II.476* & $0.003^{*}$ & $\begin{array}{l}P_{1}=0.168 \\
P_{2}=0.001 * \\
P_{3}=0.144 \\
P_{4}=0.109\end{array}$ \\
\hline
\end{tabular}

Notes: H: Kruskal-Wallis test, Pairwise comparison between each 2 groups was done using Post Hoc Test (Dunn's for multiple comparisons test). p: $\mathrm{p}$ value for comparing between the studied groups. $\mathrm{p}_{1}: \mathrm{p}$ value for comparing between control and peri-lesion SCC. $\mathrm{P}_{2}: \mathrm{p}$ value for comparing between control and lesion SCC. $\mathrm{p}_{3}$ : $\mathrm{p}$ value for comparing between peri-lesion SCC and lesion SCC. $\mathrm{p}_{4}$ : $\mathrm{p}$ value for comparing between lesion epidermis SCC and tumor islands SCC. *Statistically significant at $\mathrm{P} \leq 0.05$. Abbreviations: N, number; SD, standard deviation.

TROP2 antibodies in cases having esophageal SCC. Also, they demonstrated significantly higher TROP2 expression in esophageal SCC than immortalized and normal esophageal mucosa.

It was reported that over expression of TROP2 is associated with tumorigenesis and malignancy. ${ }^{35,36}$ TROP2 stimulates epithelial-mesenchymal transition through PI3K/ AKT signaling, thus promoting cell proliferation and migration as well as tumor metastasis ${ }^{37}$ that was reported in gallbladder cancer $^{38}$ and osteosarcoma cells. ${ }^{39}$ Additionally, TROP2 holds sites for tyrosine/serine phosphorylation that adjust signal transduction or its activity rendering tumor cell lines resistant to apoptosis. ${ }^{33}$ Furthermore, TROP2 signals through $\beta$-catenin ${ }^{40}$ that promotes the progression of tumors $^{24}$ via suppressing tumor-infiltrating $\mathrm{CD}^{+} \mathrm{T}^{+}$-cells ${ }^{41}$ which represent the major immune effector cells in antitumor immunity. ${ }^{42}$ Recently, in glioblastoma cells, it was reported that TROP2 is a regulator of JAK2/STAT3 signaling. ${ }^{43}$

In the current studied BCC and SCC cases, a nonsignificant difference exist between lesional epidermis and tumor islands TROP2 $\mathrm{H}$ scores $(\mathrm{p}=0.141$ for $\mathrm{BCC}$ and $\mathrm{p}=0.109$ for SCC), meanwhile, TROP2 $\mathrm{H}$ score of each of them was significantly higher than normal controls. Furthermore, the observed increased TROP2 H score of the studied BCC and SCC peri-lesional tissues was midway between its high values in BCC and SCC lesions, and low values of controls. These suggest that even apparently normal skin adjacent to/or covering $\mathrm{BCC}$ or SCC may harbor structural alterations at the cellular level. Supporting this result, Braakhuis et $\mathrm{al}^{44}$ reported that normal looking cells adjacent to malignant ones were genetically abnormal and were part of the transformed cells in the tumor field (skin field cancerization). These subclinical pre-neoplastic deviations are frequently present in skin that surrounds or covers the malignancy as fields of genetically cloned pre-neoplastic keratinocytes. ${ }^{45,46}$

The current study demonstrated over expression of TROP2 in BCC and SCC was not significantly affected by any of the studied clinicopathological parameters. In line with this result, Jiang et $\mathrm{al}^{22}$ reported that high TROP2 in oral SCC did not differ regarding patient age, gender and lymph node metastasis. Also, Tang et $\mathrm{al}^{24}$ revealed non-significant correlations between TROP2 expression and age, sex, tumor size, location and distant metastases.

On the other hand, Zhang et $\mathrm{al}^{25}$ reported a significant correlation of TROP2 with poorly differentiated oral SCC. Furthermore, TROP2 has been actively studied as a prognostic marker for various cancers including colon cancer and oral SCC. ${ }^{32,47}$ The difference between the results of aforementioned studies and ours could be attributed to the different types of the investigated tumors in each study.

\section{Conclusions}

Up-regulated TROP2 may actively participate in pathogenesis and development of both BCC and cutaneous SCC which open the door for its targeting as a new therapeutic modality with an appraising effect in BCC and SCC managing program.

\section{Acknowledgment}

We acknowledge the staff in Pathology Department, Faculty of Medicine, Menoufia University for their help and 
providing us with the instruments necessary for completion of the work.

\section{Funding}

No sources of funding were used to conduct this study or prepare this manuscript.

\section{Disclosure}

The authors reported no conflicts of interest in this study.

\section{References}

1. Garcovich S, Colloca G, Sollena P, et al. Skin cancer epidemics in the elderly as an emerging issue in geriatric oncology. Aging Dis. 2017;8 (5):643-644. doi:10.14336/AD.2017.0503

2. Rogers HW, Weinstock MA, Harris AR, et al. Incidence estimate of nonmelanoma skin cancer in the United States, 2006. Arch Dermatol. 2010;146(3):283-287. doi:10.1001/archdermatol.2010.19

3. Ibrahim AS, Khaled HM, Mikhail NN, Baraka H, Kamel H. Cancer incidence in Egypt: results of the national population-based cancer registry program. $J$ Cancer Epidemiol. 2014;4(1):5-6.

4. Hussein MR, Al-Badaiwy ZH, Guirguis MN. Analysis of p53 and bcl-2 protein expression in the nontumorigenic, pretumorigenic, and tumorigenic keratinocytic hyperproliferative lesions. J Cutan Pathol. 2004;31(10):643-651. doi:10.1111/j.0303-6987.2004.00244.x

5. Fania L, Didona D, Morese R, et al. Basal cell carcinoma: from pathophysiology to novel therapeutic approaches. Biomedicines. 2020;8(11):449. doi:10.3390/biomedicines 8110449

6. Apalla Z, Nashan D, Weller RB, Castellsagué X. Skin cancer: epidemiology, disease burden, pathophysiology, diagnosis, and therapeutic approaches. Dermatol Ther (Heidelb). 2017;7(1):5-19. doi:10.1007/ s13555-016-0165-y

7. Lee KJ, Soyer HP. Cutaneous keratinocyte cancers of the head and neck: epidemiology, risk factors and clinical, dermoscopic and reflectance confocal microscopic features. Oral Oncol. 2019;98:109-117. doi:10.1016/j.oraloncology.2019.09.019

8. Paolino G, Donati M, Didona D, Mercuri SR, Cantisani C. Histology of non-melanoma skin cancers: an update. Biomedicines. 2017;5 (4):71. doi:10.3390/biomedicines5040071

9. Voiculescu V, Calenic B, Ghita M, et al. From normal skin to squamous cell carcinoma: a quest for novel biomarkers. Dis Markers. 2016;2(1):3-4.

10. Kang JK, Yun BM, Song JK, Shin MS. Non-melanocytic skin cancers of the head and neck: a clinical study in Jeju Province. Arch Plast Surg. 2017;44(4):313. doi:10.5999/aps.2017.44.4.313

11. Baruah B, Sengupta S, Kesari SP, Ilapakurty B. Pattern of nonmelanoma skin cancers in Sikkim, India: a 3-year clinicopathological Review. Indian $J$ Otolaryngol Head Neck Surg. 2013;65 (1):160-162. doi:10.1007/s12070-013-0652-8

12. Lipinski M, Parks DR, Rouse RV, Herzenberg LA. Human trophoblast cell-surface antigens defined by monoclonal antibodies. Proc Natl Acad Sci U S A. 1981;78(8):5147-5150. doi:10.1073/pnas.78.8.5147

13. Linnenbach AJ, Wojcierowski J, Wu SA, et al. Sequence investigation of the major gastrointestinal tumor-associated antigen gene family, GA733. Proc Natl Acad Sci. 1989;86(1):27-31. doi:10.1073/pnas.86.1.27

14. Lenárt S, Lenárt P, Šmarda J, Remšík J, Souček K, Beneš P. Trop2: jack of all trades, master of none. Cancers. 2020;12(11):3328. doi: $10.3390 /$ cancers 12113328

15. Ning S, Guo S, Xie J, et al. TROP2 correlates with microvessel density and poor prognosis in hilar cholangiocarcinoma. $J$ Gastrointest Surg. 2013;17(2):360-368. doi:10.1007/s11605-0122105-1
16. Zeng P, Chen MB, Zhou LN, Tang M, Liu CY, Lu PH. Impact of TROP2 expression on prognosis in solid tumors: a systematic review and meta-analysis. Sci Rep. 2016;6(1):33658. doi:10.1038/srep33658

17. Rapani E, Sacchetti A, Corda D, Alberti S. Human Trop-2 is a tumorassociated calcium signal transducer. Int $J$ Cancer. 1998;76 (5):671-676. doi:10.1002/(SICI)1097-0215(19980529)76:5<671: AID-IJC10 $>3.0 . \mathrm{CO} ; 2-7$

18. Cubas R, Zhang S, Li M, Chen C, Yao Q. Trop2 expression contributes to tumor pathogenesis by activating the ERK MAPK pathway. Mol Cancer. 2010;9(1):253. doi:10.1186/1476-4598-9-253

19. Yang J, Zhu Z, Wang H, Li F, Du X, Ma RZ. Trop2 regulates the proliferation and differentiation of murine compact-bone derived MSCs. Int J Oncol. 2013;43(3):859-867. doi:10.3892/ijo.2013.1987

20. Balzar M, Briaire-de Bruijn IH, Rees-Bakker HA, et al. Epidermal growth factor-like repeats mediate lateral and reciprocal interactions of Ep-CAM molecules in homophilic adhesions. Mol Cell Biol. 2001;21(7):2570-2580. doi:10.1128/MCB.21.7.2570-2580.2001

21. Sawanyawisuth K, Tantapotinan N, Kraiklang R, et al. Suppression of trophoblast cell surface antigen 2 enhances proliferation and migration in liver fluke-associated cholangiocarcinoma. Ann Hepatol. 2016;15(1):71-81. doi:10.5604/16652681.1184223

22. Jiang A, Gao X, Zhang D, Zhang L, Lu H. Expression and clinical significance of the Trop- 2 gene in advanced non-small cell lung carcinoma. Oncol Lett. 2013;6(2):375-380. doi:10.3892/ol.2013.1368

23. Liu T, Liu Y, Bao X, Tian J, Liu Y, Yang X. Overexpression of TROP2 predicts poor prognosis of patients with cervical cancer and promotes the proliferation and invasion of cervical cancer cells by regulating ERK signaling pathway. PLoS One. 2013;8(9):e75864. doi:10.1371/journal.pone.0075864

24. Tang G, Tang Q, Jia L, et al. High expression of TROP2 is correlated with poor prognosis of oral squamous cell carcinoma. Pathol Res Pract. 2018;214(10):1606-1612. doi:10.1016/j.prp.2018.07.017

25. Zhang B, Gao S, Li R, et al. Tissue mechanics and expression of TROP2 in oral squamous cell carcinoma with varying differentiation. BMC Cancer. 2020;20(1):1-2.

26. Elston DM, Stratman EJ, Miller SJ. Skin biopsy: biopsy issues in specific diseases. $J$ Am Acad Dermatol. 2016;74(1):P1-16.

27. De Giorgi V, Savarese I, Gori A, et al. Advanced basal cell carcinoma: when a good drug is not enough. J Dermatolog Treat. 2020;31 (6):552-553. doi:10.1080/09546634.2018.1542481

28. Dalal AJ, Ingham J, Collard B, Merrick G. Review of outcomes of 500 consecutive cases of non-melanoma skin cancer of the head and neck managed in an oral and maxillofacial surgical unit in a District General Hospital. Br J Oral Maxillofac Surg. 2018;56(9):805-809. doi:10.1016/j.bjoms.2018.08.015

29. Higgins S, Nazemi A, Chow M, Wysong A. Review of nonmelanoma skin cancer in African Americans, Hispanics, and Asians. Dermatol Surg. 2018;44(7):903-910. doi:10.1097/DSS.0000000000001547

30. Shvartsur A, Bonavida B. Trop2 and its overexpression in cancers: regulation and clinical/ therapeutic implications. Genes \& Cancer. 2015;6(3-4):84. doi:10.18632/genesandcancer.40

31. Stepan LP, Trueblood ES, Hale K, Babcook J, Borges L, Sutherland CL. Expression of Trop2 cell surface glycoprotein in normal and tumor tissues: potential implications as a cancer therapeutic target. $J$ Histochem Cytochem. 2011;59(7):701-710. doi: $10.1369 / 0022155411410430$

32. Fong D, Spizzo G, Gostner JM, et al. TROP2: a novel prognostic marker in squamous cell carcinoma of the oral cavity. Mod Pathol. 2008;21(2):186-191. doi:10.1038/modpathol.3801001

33. Cubas R, Li M, Chen C, Yao Q. Trop 2: a possible therapeutic target for late stage epithelial carcinomas. Biochimica et biophysica acta. 2009;1796(2):309-314.

34. Nakashima K, Shimada H, Ochiai T, et al. Serological identification of TROP2 by recombinant cDNA expression cloning using sera of patients with esophageal squamous cell carcinoma. Int $J$ Cancer. 2004;112(6):1029-1035. doi:10.1002/ijc.20517 
35. Calvo A, Xiao N, Kang J, et al. Alterations in gene expression profiles during prostate cancer progression: functional correlations to tumorigenicity and down-regulation of selenoprotein-P in mouse and human tumors. Cancer Res. 2012;62(18):5325-5335.

36. Kowalsky CA, Faber MS, Nath A, et al. Rapid fine conformational epitope mapping using comprehensive mutagenesis and deep sequencing. J Biol Chem. 2015;290(44):26457-26470. doi:10.1074/ jbc.M115.676635

37. Tang G, Tang Q, Jia L, et al. TROP2 increases growth and metastasis of human oral squamous cell carcinoma through activation of the PI3K/Akt signaling pathway. Int J Mol Med. 2019;44(6):2161-2170. doi:10.3892/ijmm.2019.4378

38. Li X, Teng S, Zhang Y, et al. TROP2 promotes proliferation, migration and metastasis of gallbladder cancer cells by regulating PI3K/ AKT pathway and inducing EMT. Oncotarget. 2017;8(29):47052. doi:10.18632/oncotarget.16789

39. Gu QZ, Nijiati A, Gao X, et al. TROP2 promotes cell proliferation and migration in osteosarcoma through PI3K/AKT signaling. Mol Med Rep. 2018;18(2):1782-1788. doi:10.3892/ mmr.2018.9083

40. Stoyanova T, Goldstein AS, Cai H, Drake JM, Huang J, Witte ON. Regulated proteolysis of Trop2 drives epithelial hyperplasia and stem cell self-renewal via $\beta$-catenin signaling. Genes Dev. 2012;26 (20):2271-2285. doi:10.1101/gad.196451.112
41. Hong Y, Manoharan I, Suryawanshi A, et al. $\beta$-Catenin promotes regulatory $\mathrm{T}$-cell responses in tumors by inducing vitamin A metabolism in dendritic cells. Cancer Res. 2015;75(2):656-665. doi:10.1158/0008-5472.CAN-14-2377

42. Xue J, Yu X, Xue L, Ge X, Zhao W, Peng W. Intrinsic $\beta$-catenin signaling suppresses CD8+ T-cell infiltration in colorectal cancer. Biomed Pharmacother. 2019;115:108921. doi:10.1016/j.biopha.2019.108921

43. Hou J, Lv A, Deng Q, Zhang G, Hu X, Cui H. TROP2 promotes the proliferation and metastasis of glioblastoma cells by activating the JAK2/STAT3 signaling pathway. Oncol Rep. 2019;41(2):753-764. doi:10.3892/or.2018.6859

44. Braakhuis BJ, Tabor MP, Kummer JA, Leemans CR, Brakenhoff RH. A genetic explanation of slaughter's concept of field cancerization: evidence and clinical implications. Cancer Res. 2003;63(8):1727-1730.

45. Szeimies RM, Torezan L, Niwa A, et al. Clinical, histopathological and immunohistochemical assessment of human skin field cancerization before and after photodynamic therapy. Br J Dermatol. 2012;167 (1):150-159. doi:10.1111/j.1365-2133.2012.10887.x

46. Ulrich M, Maltusch A, Röwert-Huber J, et al. Actinic keratoses: non-invasive diagnosis for field cancerisation. $\mathrm{Br} J$ Dermatol. 2007;156(Suppl 3):13-17. doi:10.1111/j.1365-2133.2007.07865.x

47. Bardia A, Mayer IA, Diamond JR, et al. Efficacy and safety of anti-trop-2 antibody drug conjugate sacituzumab govitecan (IMMU-132) in heavily pretreated patients with metastatic triple-negative breast cancer. J Clin Oncol. 2017;35(19):2141. doi:10.1200/JCO.2016.70.8297

\section{Publish your work in this journal}

Clinical, Cosmetic and Investigational Dermatology is an international, peer-reviewed, open access, online journal that focuses on the latest clinical and experimental research in all aspects of skin disease and cosmetic interventions. This journal is indexed on CAS.
The manuscript management system is completely online and includes a very quick and fair peer-review system, which is all easy to use. Visit http://www.dovepress.com/testimonials.php to read real quotes from published authors. 